\title{
Medical Science Meets 'Development Aid' Transfer and Adaptation of West German Microbiology to Togo, 1960-1980
}

\author{
CAROLA RENSCH ${ }^{1}$ and WALTER BRUCHHAUSEN ${ }^{1,2,3 *}$ \\ ${ }^{1}$ University of Bonn, Medical Faculty, Sigmund-Freud-Str. 25, D-53127 Bonn, Germany \\ ${ }^{2}$ Institute for the History, Theory and Ethics, RWTH Aachen University, \\ Medical Faculty, Wendlingweg 2, D-52074 Aachen, Germany \\ ${ }^{3}$ Institute for the History of Medicine and Medical Ethics, University of Cologne, \\ Medical Faculty, Joseph-Stelzmann-Strasse 20, D-50931 Cologne, Germany
}

\begin{abstract}
After losing the importance it had held around 1900 both as a colonial power and in the field of tropical medicine, Germany searched for a new place in international health care during decolonisation. Under the aegis of early government 'development aid', which started in 1956, medical academics from West German universities became involved in several Asian, African and South American countries. The example selected for closer study is the support for the national hygiene institute in Togo, a former German 'model colony' and now a stout ally of the West. Positioned between public health and scientific research, between 'development aid' and academia and between West German and West African interests, the project required multiple arrangements that are analysed for their impact on the co-operation between the two countries. In a country like Togo, where higher education had been neglected under colonial rule, having qualified national staff became the decisive factor for the project. While routine services soon worked well, research required more sustained 'capacity building' and did not lead to joint work on equal terms. In West Germany, the arrangement with the universities was a mutual benefit deal for government officials and medical academics. West German 'development aid' did not have to create permanent jobs at home for the consulting experts it needed; it improved its chances to find sufficiently qualified German staff to work abroad and it profited from the academic renown of its consultants. The medical scientists secured jobs and research opportunities for their postgraduates, received grants for foreign doctoral students, gained additional expertise and enjoyed international prestige. Independence from foreign politics was not an issue for most West German medical academics in the 1960s.
\end{abstract}

Keywords: Development Aid, Academic co-operation, Public Health, Hygiene, Togo

* Email address for correspondence: walbruch@uni-bonn.de

Part of the research was sponsored by the DFG within the research project BR2522-3-1. We would like to thank Iris Borowy and the anonymous reviewers for their very helpful comments, and Carolyn Kenny for careful language editing. 
Joint biomedical research, academic co-operation between institutions in the northern and southern hemispheres, and equal opportunities for scientists from former colonies - these are some of the demands currently being made by a number of global health activists and by critics of the present-day approaches to global health. ${ }^{1}$ This new focus is a response to the obvious neglect of these fields in previous years, when massive pressure on scientists in the global north to collect impact factors and to obtain external funding resulted in a different orientation: attention was paid to issues which were likely to yield rewards in these areas rather than to matters concerning the health problems of deprived populations and the activities of research institutions in Low Income Countries. The recent interest in global health, however, where governments and 'philanthropo-capitalists' have allocated more funding to research on 'neglected', 'poverty-related' or 'tropical' diseases than ever before, is not the first instance in the last hundred years where medical academics have discovered 'developing countries' as a field offering new opportunities for engagement as well as jobs, career prospects, renown, research, publications or additional funding coupled with the satisfaction of aiding the especially needy, and experiencing exotic cultures. Previous opportunities of this kind also existed for a considerable number of scientists from universities in industrialised nations both during and shortly after decolonisation although and perhaps also because internationally active agencies like the World Health Organization (WHO) developed their own expertise and staff for matters of health in the 'young nations' during these years. ${ }^{2}$

The present focus on north-south co-operation in the field of research in the medical and health sciences as well as in politics and philanthropy ('public-private-partnerships') ties in with similar issues currently being explored in the history and anthropology of health, medicine and the biosciences. This emerging new interest in entangled institutional history is likely to increase in the future and follows a period during which the subject of health and research in Africa or other tropical regions since 1945 has mainly been found in 'biographies' or other histories of single diseases. ${ }^{3}$ Most recent scientific and technology studies on institutions in African countries have been preoccupied with micro-histories of colonial institutes and their aftermath or with the African part of the asymmetric north-south relationship of scientists in the colonial and independent eras. ${ }^{4}$

${ }^{1}$ Jeffrey P. Koplan et al. for the Consortium of Universities for Global Health Executive Board, 'Towards A Common Definition of Global Health', Lancet, 373 (2009), 1993-5; Paul Wenzel Geissler and Ferdinand Okwaro, 'Developing World: Discuss Inequality', Nature, 513, 18 (2014), 303.

${ }^{2}$ WHO (ed.), The Second Ten Years of the World Health Organization, 1958-67 (Geneva: WHO, 1968), 82-5, 87-92.

${ }^{3}$ For example, Randall M. Packard, White Plague, Black Labor: Tuberculosis and the Political Economy of Health and Disease in South Africa (Berkeley, CA: University of California Press, 1990); John Farley, Bilharzia: A History of Imperial Tropical Medicine (Cambridge: Cambridge University Press, 1991); John Iliffe, The African AIDS Epidemic: A History (Athens, OH: Ohio University Press, 2006); Sanjoy Bhattacharya, Expunging Variola: The Control and Eradication of Smallpox in India, 1947-77 (New Delhi: Orient Longman, 2006); Randall M. Packard, The Making of a Tropical Disease: A Short History of Malaria (Baltimore, MD: The Johns Hopkins University Press, 2007), 143-251; Myron Echenberg, Africa in the Time of Cholera: A History of Pandemics from 1817 to the Present (Cambridge: Cambridge University Press, 2011), 87-183; James L. A. Webb, Jr., The Long Struggle against Malaria in Tropical Africa (Cambridge: Cambridge University Press, 2014), 69-172; contributions in Tamara Giles-Vernick and James L. A. Webb, Jr. (eds), Global Health in Africa: Historical Perspectives on Disease Control (Athens, OH: Ohio University Press, 2012).

${ }^{4}$ For example, Guillaume Lachenal, 'Franco-African familiarities: a history of the Pasteur Institute of Cameroun, 1945-2000', in Mark Harrison, Margaret Jones, and Helen Sweet (eds), From Western Medicine to Global Medicine: The Hospital Beyond the West (New Delhi: Orient BlackSwan, 2009), 411-4; Noemi Tousignant, 'Broken Tempos: Of Means and Memory in a Senegalese University Laboratory', Social Studies of Science, 43, 5 (2013), 729-53. 
Theorised in terms of exclusion, peripheralisation, subjugation or marginalisation, the various histories, ethnographies or other narratives of these situations contrast sharply with the noted optimism of continuous progress characteristic of scientists themselves in most places. While the 1980s have been classified as the 'lost decade for development' by the UN Intellectual History Project ${ }^{5}$ among others, the decades before and after were full of great expectations. The earlier heyday of the transfer of knowledge, methods and materials to Africa, made possible by the co-operation of medical scientists with 'development aid' shortly after independence, was motivated by an optimism which is somehow similar to the current ambitious health objectives found in the transition from the Millennium Development Goals (MDGs) to the Sustainable Development Goals (SDGs). The post-independence period with its often naïve expectations and extensive innovations in international co-operation on health and other areas will be the focus of this study.

\section{Research Questions and Material: Medical Science through 'Development Aid'}

This study regards itself as a supplement to the common melancholy of failed expectations, contrary effects, unfulfilled promises and the generally deplorable state of affairs lamented in much of the mainstream anthropological and historical literature. It aims to achieve a more dynamic perspective by asking when, how and why the initial optimism was fuelled or frustrated in the course of the projects. Instead of focusing exclusively on the constructions of the periphery, ie. the African part and its agency, as is the tendency among established African scholars of history and anthropology due to their professional perspective, this paper seeks to explore more of the European activities both within and outside Europe. Since studies of medical science in European countries after the Second World War rarely touch on relations with former colonies, there seems to be an imbalance between the number of historical and anthropological studies devoted to the European activities compared to those devoted to the African side in these encounters. Furthermore, a renewed examination of the institutions and personnel of the northern hemisphere that dominated the early triumphant histories of colonial medicine and science can shed new light on these: the emphasis on African agency in more recent studies calls for a reversed and complementary perspective focusing on the Europeans, who would then have to be seen as being greatly changed in the encounter, often learning as much themselves as they were attempting to teach the Africans. Thus these two shifts - a 'procedural turn' from the rather static description of results to the dynamics of transfer and interaction, and a 'Eurocentric turn' from the modifying 'recipients' to the modifications of the 'donor' side - will be some of the primary perspectives of this article.

The particular scenario to be examined is that of transfer processes between two countries in Western Europe and West Africa. Regarding this binational focus, it is important to note that, unlike most studies on white protagonists in Africa after independence, this paper has not chosen a recent European colonial power with many continuing ties to African countries. It looks, instead, at the special case of Germany. A considerable number of academics and academic institutions in the Federal Republic of Germany (FRG) were among those involved in the re-establishment of a German role in health care in tropical and sub-tropical countries within the new framework of Western

\footnotetext{
${ }^{5}$ United Nations Intellectual History Project, 'Briefing Note 7' (May 2010), 4, www.unhistory.org/briefing/ 7UNandDevStrategies.pdf.
} 
'development aid'. (An Eastern European state like the German Democratic Republic (GDR), by contrast, called its more modest efforts 'international solidarity'). ${ }^{6}$ During the first UN 'development decade' (1960-69), at a time when 'development' was still mainly understood in economic terms, $8 \%$ of the West German budget for 'technical aid' was allotted to the health sector, at a total of 130 million Deutschmarks for 176 projects. $^{7}$ Africa became the main regional focus of West German 'technical and personnel aid' in health, whereas the main focus of aid in the Middle East, for example, was vocational training. This was due to a variety of reasons, notably extraordinary local need, the absence of infrastructure necessary for immediate industrialisation, previous colonial, diplomatic, academic and medical relations as well as contemporary power politics. The African recipients included countries north and south of the Sahara, with a focus in the 1960s on Ethiopia, Algeria, Senegal, Niger and Togo. ${ }^{8}$ West German expert medical academics were involved in most of the major health projects. In view of this, the German-Togolese relationship in microbiology within the framework of 'development aid' in the 1960s and 1970s was chosen as an example for closer study.

The article will first give a short summary of post-colonial, pre-1945 German academic interest in health outside the North Atlantic world, continuing with an overview of West German academic activities in health in non-European countries and of the relationship between the academic world and West German political and administrative structures in 'development aid' and research policy. The main part of the article will consist of an extensive case study concerning Togo. This includes an examination of international co-operation on the part of several institutes at West German universities which did not have a long pre-war tradition of medical research in the tropics: the Institute of Comparative Tropical Medicine in the Veterinary Faculty at Munich University, the Institutes of Hygiene and of Parasitology at Bonn University and the Hygiene Institute of Würzburg University. The directors of these institutes responded to the idea that political independence should be followed by scientific independence and they actively supported the creation of a microbiological institute in a sub-Saharan state, the Institut National d'Hygiène in Togo.

Inevitably, the dynamics of this project were rooted in the earlier background of German academic activities in tropical medicine as well as in later policies for West German 'development aid' and international academic policies. Thus - refraining from the contested issue of the positive or negative impact on the host country's health situation - the second major question to be examined in this study will be the relationship between 'development aid' and medical science. Was it one of mutual benefit and understanding, or did one of the two have to suffer due to pressure from the other's special interests? Such a question on the relationship between medical research and politics as possible 'resources for each other' has been explicitly posed and widely discussed with regard to National

\footnotetext{
${ }^{6}$ Walter Bruchhausen, 'Export und Import von Medizinern und Gesundheitspolitik: Zur Erforschung des deutschen Engagements für Entwicklungsländer nach 1950', in Heiner Fangerau and Igor Polianski (eds), Medizin im Spiegel ihrer Geschichte, Theorie und Ethik (Stuttgart: Steiner, 2012), 51-70.

${ }^{7}$ Jack Knusel, West German Aid to Developing Nations (New York: Praeger, 1968); BArch (Bundesarchiv [Federal Archive] Koblenz) B213/4960 Fragen des Gesundheitswesens 1970/71, Folder III A/7-T9010 Gesundheitspolitik in der BRD (Gesundheitsbericht), Scheiber, BMZ Referat I B 6, Anlage zum Vermerk vom 6.8.1970.

${ }^{8}$ BArch B213/4960 Fragen des Gesundheitswesens 1970/71, Folder III A/7-T9010 Basisklinik für Entwicklungsländer (Dr Nonnemann) 26.3.71, Zusammenstellung einiger wichtiger Gesundheitsprojekte der deutschen Technischen Hilfe (i.e.S.) - Stand 31.12.1969.
} 
Socialism in Germany. ${ }^{9}$ A similar question - although with much less emphasis on eventual guilt for crimes and failures - is present in much writing on colonial medicine. ${ }^{10}$ A study on the British Colonial Medical Research Committee until 1950, ${ }^{11}$ for example, recently addressed this issue for a scenario not unlike this West German case - without exploring moral connotations.

Being sceptical towards theoretical monism, the approach chosen here will combine several perspectives from different discourses. In the light of functionalist systems theory, ${ }^{12}$ medical academia (as part of science) and 'development aid' (as part of politics and administration) will be treated as functional social systems of communications with their own specific objectives, rewards and procedures which render their 'coupling' potentially difficult. But it is also important to question and deconstruct these notions since neither academia nor 'development aid' in their new African settings were fixed entities in accordance with an official definition but had to be re-invented in the course of their establishment. These processes will be investigated using the praxeological approach. This looks at 'practices' such as scientific research and training with their core material means of biological samples, laboratory results and publications on the one hand, ie. the academic side, and 'practices' such as planning, agreements, recruiting and practical training on the other hand, ie. the developmental side. As these different functional systems and sets of practices often exist side by side within the same projects, institutions and persons, their interaction can be studied in multiple ways. Apart from the focus on medical research, the additional aims of this article include further investigation of the general relationship between 'development (aid)' and health, as this subject has been the focus of increased attention over recent years. ${ }^{13}$

As this article focuses on the German side in the encounter, the sources used were from four German archives and from German and international journals only. Unfortunately, none of the main protagonists mentioned could be interviewed as eyewitnesses as they are already deceased. The academic part of the history is documented in the archives of the University of Bonn and the two grant-giving institutions for academic

\footnotetext{
${ }^{9}$ Mitchel Ash, 'Wissenschaft und Politik als Ressourcen für einander', in Rüdiger vom Bruch (ed.), Wissenschaften und Wissenschaftspolitik: Bestandaufnahmen zu Formationen, Brüchen und Kontinuitäten im Deutschland des 20. Jahrhunderts (Stuttgart: Steiner, 2002), 32-51; Hans-Walter Schmuhl, “ "Resources for Each Other": The Society of German Neurologists and Psychiatrists and the Nazi "Health Leadership" ', European Archive for Psychiatry and Clinical Neurosciences, 261, Suppl 2 (2011), 197-201; Matthis Krischel, Friedrich Moll and Heiner Fangerau, 'Die 1907 gegründete "Deutsche Gesellschaft für Urologie" und die "Gesellschaft Reichsdeutscher Urologen” im Nationalsozialismus', Der Urologe, 50, 9 (2011), 1154-60.

${ }^{10}$ Michael Worboys, 'Tropical diseases', in William F. Bynum and Roy Porter (eds), Companion Encyclopedia of the History of Medicine vol. 1, (London: Routledge, 1993), 512-36; Wolfgang U. Eckart, Medizin und Kolonialimperialismus: Deutschland 1884-1945 (Paderborn: Schöningh, 1997), 25-90; Helen Tilley, Africa as a Living Laboratory: Empire: Development and the Problem of Scientific Knowledge 1870-1950 (Chicago, IL: University of Chicago Press, 2011).

${ }^{11}$ Sabine Clarke, 'The Research Council System and the Politics of Medical and Agricultural Research for the British Colonial Empire, 1940-52', Medical History, 57 (2013), 338-58.

12 Samantha Meyer, Barry Gibson and Paul Ward, 'Social systems theory and the translation of public health research', in Fran Collyer (ed.), The Palgrave Handbook of Social Theory in Health, Illness and Medicine (Basingstoke: Palgrave Macmillan, 2015), 340-54.

${ }^{13}$ Lukas Meier, Swiss Science, African Decolonization and the Rise of Global Health, 1940-2010 (Basle: Schwabe, 2014); Marcel Dreier, Health, Welfare and Development in Rural Africa: Catholic Medical Mission and the Configuration of Development in Ulanga,Tanzania, 1920-70, (unpublished PhD thesis: University of Basle, 2014); Walter Bruchhausen, 'From precondition to goal of development: health and medicine in the planning and political conflicts of British Tanganyika Territory', in Joseph M. Hodge, Gerald Hödl, and Martina Kopf (eds), Developing Africa: Concepts and Practices in Twentieth-Century Colonialism (Manchester: Manchester University Press, 2014), 207-21.
} 
activities, the German Research Foundation (DFG) for research and the German Academic Exchange Service (DAAD) for international co-operation between academic institutions. The governmental contribution, mainly in the form of the then Ministry of Economic Co-operation (BMZ), ${ }^{14}$ was examined on the basis of documents in the German Federal Archives (BArch). It was possible to gain an instructive insight into the different goals, concepts and strategies of these unequal partners by contrasting sources from academia and government. The common temptation to treat the European side in north-south relations as rather monolithic in nature could be countered here by indicating the effects of classic conflicts of interest, especially those between the intellectual, universal and longterm perspective of science and the more practical, national and short-term aims of politics.

\section{Background: Tropical Medicine, 'Development Aid' and Academia in Germany}

For several reasons Germany occupies a somewhat exceptional place in the history of the interaction between medical academia and health politics at an international level. German academia achieved scientific prestige in the early years of research in tropical medicine with authorities such as Robert Koch in Berlin or renowned institutions such as the Institute for Naval and Tropical Diseases in Hamburg, founded in $1900 .{ }^{15}$ But after the First World War, German research was affected by the loss of colonies and by restricted access to tropical territories. Consequently, the activities of German experts outside Germany consisted of the participation in expeditions and in international commissions of the League of Nations. ${ }^{16}$ Under National Socialist rule and during the Second World War, temporary plans to restore a German empire in Africa and the military campaigns in North Africa and southern Europe led to renewed political interest in tropical medicine and hygiene. ${ }^{17}$ This contributed to the establishment of relevant academic disciplines and institutes, eg. parasitology at the University of Bonn in a department of the Institute of Pharmacology in $1943 .^{18}$

After the war, the situation was again different from that of the colonial powers of the period. There was no special interest in work on other continents in any of the German research councils, let alone a new Colonial Research Service such as existed in Britain. ${ }^{19}$

\footnotetext{
14 After a previous Ministry of Economic Co-operation devoted to European co-operation by funds of the Marshall Plan (European Recovery Programme) in the 1950s, a second Ministry of Economic Co-operation designed to administrate 'development aid' was funded in 1961 and renamed as the Ministry of Economic Co-operation and Development in 1993. In order to avoid confusion. It will be also referred to as ministry of development co-operation, emphasising the function, not the changing names.

15 Christoph Gradmann, Krankheit im Labor: Robert Koch und die medizinische Bakteriologie (Göttingen: Wallstein, 2005); Wolfgang U. Eckart, "Von der Idee eines "Reichsinstituts" zur unabhängigen Forschungsinstitution', in Rüdiger vom Bruch and Rainer A. Müller (eds), Formen außerstaatlicher Wissenschaftsförderung im 19. und 20. Jahrhundert (Stuttgart: Steiner, 1990), 31-52; Wolfgang U. Eckart, 'Die Anfänge der deutschen Tropenmedizin: Die Gründung des Hamburger Instituts für Schiffs- und Tropenkrankheiten', in Heinz Schott (ed.), Meilensteine der Medizin (Dortmund: Harenberg, 1996), 411-8; in 1990 it was renamed, after the founding director, as the Bernhard-Nocht-Institute of Tropical Medicine.

${ }^{16}$ Iris Borowy, Coming to Terms with World Health: The League of Nations Health Organization 1921-46 (Frankfurt am Main: Lang, 2009), 146; Eckart, op. cit. (note 10), 505-1.

${ }^{17}$ Deutsche Tropenmedizinische Gesellschaft, (ed.), Koloniale Gesundheitsführung in Afrika: Verhandlungen der 11. Tagung der Deutschen Tropenmedizinischen Gesellschaft vom 3.-5. Oktober 1940 in Hamburg (Leipzig: Barth, 1941).

${ }^{18}$ Florian Stader, Geschichte der Parasitologie an der Universität Bonn, (Dr med. dissertation: University of Bonn, 1986), 30-4; Ralf Forsbach, Die Medizinische Fakultät der Universität Bonn im 'Dritten Reich' (Munich: Oldenbourg, 2006), 110-11: 583.

${ }^{19}$ Clarke, op. cit. (note 11).
} 
Another orientation was thus necessary for all the German disciplines related to tropical climates. In tropical agricultural research, the purpose of the discipline was quickly shifted from supporting German settlers and those of other nationalities to 'development aid'. ${ }^{20}$ In medicine, decolonisation provided new opportunities for academic specialists dependent on contact with tropical regions, notably parasitologists or bacteriological experts on cholera and other diarrhoeal diseases. In addition, the decline of smallpox, tuberculosis and other infectious diseases in Germany freed up capacity for the support of antiinfectious hygiene and vaccination initiatives outside Europe. West Germany thus regained the necessary preconditions for a role in international medicine and health, ie. a sufficient supply of well-qualified scientists and the renewal of economic and diplomatic influence that had been lost after the First World War. Medical scientists now readily seized the opportunities offered by the bilateral 'technical assistance for under-developed countries' (Technische Hilfe für unterentwickelte Länder) started by West Germany in 1956. Thus the complex relationship between academia and 'development aid' (as parts of the differing social systems of science and politics) began in the context of Cold War. Neither system was well prepared for this common task.

The West German government had no established administrative system of medical 'development aid' when the first West German university institutes and hospitals started their engagement in Asia, Africa and Latin America in the early 1960s. Government funds for health had first been used to support the German Christian medical missions, which continued and even increased their pre-war programmes of sending health workers, equipment and material overseas and of training local health staff. The first so-called Entwicklungshelfer [development aid workers] of the new Deutscher Entwicklungsdienst (DED) [German Development Service, a volunteer service for professional staff modelled on the US Peace Corps, did not leave Germany until 1964. In the period up to October 1965, just ten of these members of staff - fewer than five per cent - held a university degree. This prompted DED managers to think about job opportunities for university graduates at universities in 'developing countries'. ${ }^{21}$ Another agency of the West German government in charge of development issues, the GAWI (Garantieabwicklungsgesellschaft), also sent some medical specialists. ${ }^{22}$ Requested by friendly governments, they worked in major hospitals, mainly in Ethiopia, Algeria and Togo. Meanwhile, several hundred other German physicians had continued to work in government health facilities in decolonised countries, especially in the Middle East and in South-East Asia without their work being organised or supported by West German government agencies. ${ }^{23}$

In the 1960s, West German 'development aid' was officially subject to three principles: 'application', 'non-attachment' and 'project'. These principles meant that aid would only be granted at the explicit request of the national government in the form of a project proposal, that financial aid would not commit recipients to buy the required equipment

${ }^{20}$ Eckhard Baum, Daheim und überm Meer: Von der Deutschen Kolonialschule zum Deutschen Institut für Tropische und Subtropische Landwirtschaft in Witzenhausen (Witzenhausen: Selbstverlag des Verbandes der Tropenlandwirte, 1997), 181-207.

${ }^{21}$ Bastian Hein, Die Westdeutschen und die Dritte Welt: Entwicklungspolitik und Entwicklungsdienste zwischen Reform und Revolte 1959-74 (Munich: Oldenbourg, 2006), 87.

${ }^{22}$ Founded by the German Government as the Garantieabwicklungsgesellschaft before the Second World War, the GAWI was renamed as the Deutsche Förderungsgesellschaft für Entwicklungsländer [German Agency for Promoting Developing Countries] and first commissioned to acquire and send material as well as staff, later also to plan, to advise and to conduct co-operative projects of its own.

${ }^{23}$ K. Brüning, 'Drei Jahre Chirurg auf der Sundainsel Lombok: Erlebnis und Tätigkeitsbericht aus Indonesien', Deutsche medizinische Wochenschrift, 84 (1954), 117-9; Alfred Virnich, 'Deutsche Ärzte im Irak', Deutsche Medizinische Wochenschrift, 79 (1954), 1691-3. 
in Germany and that the aid was tied to the agreed projects and could not consist of grants to the general budget or of the mere delivery of goods. ${ }^{24}$ While these principles were often handled in a rather cavalier manner in practice, they did nevertheless establish the basis required for scientific and medical co-operation: New hospitals or institutes were not offered, but had to be requested by the governments of the partner countries; the means granted were bound to these institutions and could not be used for other health care or research purposes; and the construction, equipment and supply was not necessarily commissioned with German companies.

Although the West German government also financed multilateral organizations such as the WHO, it systemically prioritised aid to individual states, as this offered better opportunities for pursuing its interests in foreign politics. The West German report for the Development Assistance Committee (DAC) of the Organization for Economic Cooperation and Development (OECD) of 1962 stated bluntly that 'The Federal Government prefers bilateral assistance.' ${ }^{25}$ Within health, it especially supported medical education, training and research. Typically, health projects for research and practice were negotiated and operated between two governments, with an international agency fulfilling an advisory function. Following the wishes of its member states, the WHO itself had to refrain from establishing its own research institutes. Instead, it worked with 'collaborating centres' in several member countries and received support from its technical departments in Geneva as a kind of substitute for proper research institutes of its own. Restriction on multilateral activities remained a feature of German development aid beyond political parties and coalitions. In the 1970s, the West German preference for unilaterally sending experts and development workers even increased dramatically when Erhard Eppler, the minister responsible for development co-operation, and Chancellor Willy Brandt demanded a doubling of their numbers within five years. ${ }^{26}$ Despite opposition from the ministries of health and foreign affairs, the ministry of development co-operation, which had been created for managing 'development aid' in 1961, was finally given responsibility for all projects of 'technical assistance' in $1965 .{ }^{27}$ It relied on the GAWI, later renamed the GTZ ${ }^{28}$ for the planning and implementation of the projects.

The situation regarding medical research and education outside Germany as distinct from 'technical assistance' was even more unclear, however, since this also touched on responsibilities which were located within yet another area. This was the area of the Federal Ministry of Education and Science (BMBW) founded in 1969, which in turn sponsored two further agencies, the DAAD and DFG. ${ }^{29}$ Thus various different parties

\footnotetext{
${ }^{24}$ Hein, op. cit. (note 21), 55-9.

25 OECD Archive DAC/AR (62) 8 Subject: Annual Review 1962 of the Development Assistance Efforts and Policies of the Members of the Development Assistance Committee, Reference: Memorandum of the Federal Republic of Germany, 2.

${ }^{26}$ Hein, op. cit. (note 21), 193.

27 Ibid., 113.

28 This Gesellschaft für technische Zusammenarbeit (GTZ) [Agency for Technical Co-operation] was created by merging the GAWI and the Bundesstelle für Entwicklungshilfe (BfE) [Federal Office for Development Aid] in 1975. Today, after further fusions, amongst others with the DED, it is called the GIZ [Agency for International Co-operation].

29 The Bundesministerium für Bildung und Wissenschaft was the second largest donor to the Deutscher Akademischer Austauschdienst (DAAD) [German Academic Exchange Service] after the Foreign Office; the major funding agency for research projects, the Deutsche Forschungsgemeinschaft (DFG) [German Research Fund], was jointly financed by the federal government (through the BMBW) and the provincial states (Bundesländer) of Germany; on funding research on tropical medicine by the DFG, see Marion A. Hulverscheidt, 'Fieberhafte Forschung? Zur Deutschen Tropenmedizinischen Wissenschaft im Spiegel ihrer Förderung durch die Notgemeinschaft/Deutsche Forschungsgemeinschaft 1920-70', in Karin Orth and Willi Oberkrone (eds),
} 
were involved: not only the donor and recipient countries as such, but also various public donors in Germany and various recipients - the project partners in Germany and in the foreign country. The situation was highly complex, mirroring German federalism and thereby fundamentally differing from the centralism of France and Britain, where the 'Pasteurians' and Orstom (Office de la Recherche Scientifique et Technique Outre Mer) or the Medical Research Council respectively controlled overseas microbiological work in terms of staffing, funding and research direction. ${ }^{30}$

Universities had to find their position within this particular and rather complicated framework of West German 'development aid' and research funding. At the time, curative medicine in rural hospitals in Africa and South or South-East Asia had been left to the German Christian missions. The fields of hygiene and public health were regarded by experts as most important for solving the health problems of 'developing countries'. Hygiene institutes - in addition to medical education and teaching hospitals - therefore became a major focus of early West German 'development aid'. There are several examples of this kind of co-operation with areas of focus quite characteristic of the respective countries. In Kabul, Professor Fritz Fühner of the Hygiene Institute of Hamburg first oversaw the establishment of a hygiene institute at the university from 1960 to 1963 and, from 1964 onwards, the creation of a similar service at national level. For this purpose, he headed a team of ten German expatriates who were responsible for virology, clinical chemistry and haematology as well as for the inspection of food, water and drugs. The microbiology, health education and epidemiology units, on the other hand, were organised by the WHO. ${ }^{31}$ In Bangkok, the Public Health Research Institute received its equipment from the FRG and had four West German staff members in 1969. ${ }^{32}$ The Hamburg Institute for Naval and Tropical Diseases, when asked for advice on laboratory equipment, established a programme of co-operation with the Tropical Institute at the University of Lima in the early 1960s. ${ }^{33}$ The Hamburg institute also founded a research centre in Bong Mine, Liberia in 1968. An example of early academic co-operation well known to the West German public due to its tragic ending was a project by the medical faculty of Freiburg University, which created a medical school in Hué, the ancient imperial city of Vietnam, in $1961 .{ }^{34}$ It was devoted to medical education only and succeeded in qualifying its first medical doctors before the project was discontinued due to the murder of three German physicians and the head of mission's wife by the 'Vietcong' in 1968.

Die Deutsche Forschungsgemeinschaft 1920-70: Forschungsförderung im Spannungsfeld von Wissenschaft und Politik (Stuttgart: Steiner, 2010), 279-92.

${ }^{30}$ Lachenal, op. cit. (note 4), 423; Guillaume Lachenal, 'The intimate rules of the French coopération: morality, race and the postcolonial division of scientific work at the Pasteur Institute of Cameroon', in Paul Wenzel Geissler and Catherine Molyneux (eds), Evidence, Ethos and Ethnography: The Anthropology and History of Medical Research in Africa (Oxford: Berghahn, 2011), 373-401; Clarke, op. cit. (note 11).

${ }^{31}$ Professor Dr med. F. Fühner, 'IV. Hygiene der Entwicklungsländer', from: Hygienisches Institut der Freien und Hansestadt Hamburg (ed.), Arbeitsbericht des Direktors der Lehranstalt für Allgemeine und Sozial-Hygiene, Jahrgang 1966, BArch B213/4960 Fragen des Gesundheitswesens 1970/71, Folder Projektleitertagungen Gesundheitshilfe - 1968 - und Fachtagung(en) (Niger).

32 'Zusammenstellung einiger wichtiger Gesundheitsprojekte der deutschen Technischen Hilfe (i.e.S.) Stand 31.12.1969', BArch B213/4960 Fragen des Gesundheitswesens 1970/71, Folder Basisklinik für Entwicklungsländer (Dr Nonnemann) 26.3.71.

${ }^{33}$ Maria Daelen, 'Probleme der Entwicklungshilfe auf dem ärztlich-medizinischen Sektor', Ärztliche Mitteilungen, 47 (1962), 1633-9.

${ }^{34}$ Georg W. Alsheimer [alias Erich Wulff], Vietnamesische Lehrjahre: Sechs Jahre als deutscher Arzt in Vietnam, 1963-7 (Frankfurt am Main: Suhrkamp, 1968); Simon Reuter, Im Schatten von Tet: Die Vietnam-Mission der Medizinischen Fakultät Freiburg (1961-8) (Frankfurt am Main: Lang, 2011). 
Co-operation with countries not affected by a proxy war in the East-West conflict was of longer duration. However, such co-operation was also often affected by side-effects of the Cold War, as in the case of the Theodor Bilharz Institute in Egypt funded by the FRG. Here, construction was delayed, though not completely interrupted, for several years following the suspension of diplomatic relations between Egypt and the FRG from 1965 to 1972, which had occurred as a result of the state visit of the East German head of state Walter Ulbricht to Cairo. ${ }^{35}$

In overall terms it can be said that several West German institutes and medical scientists had already received government or other public support to develop healthrelated academic infrastructure in African, Asian and Latin American countries before joint scientific research was explicitly included in 'development aid'. It was only in the late 1960s that Germany publicly looked at British practice as a possible role model for international co-operation between universities, extending an invitation to Professor C. T. Ingold, Vice-Chair of the London-based Inter-University Council for Higher Education Overseas ${ }^{36}$ to speak in Germany. Ingold, who was a renowned mycologist himself (and father of the later famous anthropologist Tim Ingold), presented British policies and experiences to a German audience in 1969 and emphasised the need for political independence on both sides as well as flexibility and the avoidance of paternalistic 'neocolonialism'. Two years later, in 1971, co-operation in science and higher education became an official part of West German 'development aid' ${ }^{37}$

Nearly a decade before this, one of the earlier, in many ways pioneering, projects linking the German government focus on public health to German academia was already in place in the small West African state of Togo.

\section{The Setting: Institut National d'Hygiène in Lomé, Togo}

German medical relations with Togo had already had a long tradition before the country became independent of France in 1960. Having previously been part of the West African region known as the 'slave coast' and of the Portuguese trade network, the territory of the present Republic of Togo and of the Upper Volta region of Ghana was proclaimed as the German 'Protectorate of Togo' in 1884 by a medical doctor, Gustav Nachtigal (1834-85), who was then also German consul in Tunis and German imperial commissioner for West Africa. ${ }^{38}$ Being a so-called 'model colony' (Musterkolonie), Togo experienced various German activities in the fields of health care and medical research, ${ }^{39}$ amongst them the first German government hospital in tropical Africa. ${ }^{40}$ Internationally famous German doctors

35 Thomas W. Kramer, Deutsch-ägyptische Beziehungen in Vergangenheit und Gegenwart (Tübingen: Erdmann, 1974), 282.

${ }^{36}$ Cecil Terence Ingold, 'Die Zusammenarbeit zwischen Universitäten des United Kingdom und Universitäten in Entwicklungsländern', Almanach 1970 der Deutschen Stiftung für Entwicklungsländer (Berlin: DSE, 1970), 97101. The Inter-University Council for Higher Education Overseas in London had been founded after the report of the Colonial Higher Education Commission (Asquith Commission) in 1945. His invitation and the conference near Bonn in October 1969 were organized by the Deutsche Stiftung für Entwicklungsländer (DSE) [German Foundation for Developing Countries], yet another federalist agency for development then engaged in issues of international health.

${ }^{37}$ Grundsatzprogramm der Bildungs- und Wissenschaftshilfe (Bonn: Bundesministerium für wirtschaftliche Zusammenarbeit, 1972).

${ }^{38}$ Claus Priesner, 'Nachtigal, Gustav', Neue Deutsche Biographie, 18 (Berlin: Duncker \& Humblot, 1997), $682-4$.

${ }^{39}$ Eckart, op. cit. (note 10), 122-85.

${ }^{40}$ Guenter Rutkowski, Die deutsche Medizin erobert Togo: Beispiel des Nachtigal-Krankenhauses in Klein-Popo (Anecho), 1884-1914 (Hamburg: Diplomica, 2012). 
like the 'discoverer' of the smallpox virus, the pathologist Enrique Paschen (1860-1936; in Togo 1911-12), and the hygienist Ernst Rodenwaldt (1878-1965; in Togo 1909-13) worked in the colony before it came under French and British control during the First World War. ${ }^{41}$ The official division into British Togoland and French Togoland as a League of Nations mandate in 1922 finally led to the present situation, the British part being incorporated into the Gold Coast, later Ghana, and the French part retaining the name and forming the Republic of Togo. Although France had also introduced its common West African health system here, French Togoland had not received institutions for the higher education of health professionals or for medical research in the same way as other French territories in West Africa such as Senegal, Cameroon, Congo-Brazzaville or the Central African Republic.

Immediately after independence in 1960, the new Republic of Togo and the FRG signed a bilateral agreement, which also included health. ${ }^{42}$ The first prime minister and subsequent president of Togo, Sylvio Olympio (1902-63), was especially interested in these relations with the first colonial power. ${ }^{43}$ His cousin Pedro Olympio (1898-1969), after education at secondary schools in the Netherlands and Germany run by a German missionary society, had studied medicine at the universities of Bonn and Munich and had worked temporarily at the Hamburg Institute for Naval and Tropical Diseases before undertaking further studies in Paris and returning to his native country as the first Togolese physician educated and trained in Europe. ${ }^{44}$ It seems to have been this special interest in Germany which led to the official agreement on technical co-operation, including first ideas for a national institute of hygiene, more than a year before West Germany even had a ministry responsible for development co-operation. Given the early contacts in the area of hygiene, the government of Togo requested West German assistance in this particular field - while ignoring conflicts and repression the German colonial administration had caused, especially in the field of public health. ${ }^{45}$ The absence of an Institut Pasteur, however, was probably a more important actual reason than mere colonial nostalgia or anti-French sentiment.

The co-operation between the federal government and medical academia in Germany which became necessary for the agreed German intervention in the field of hygiene in Togo was facilitated by the contacts of Professor Dr med. Horst Habs (1902-87), who had been director of the Hygiene Institute at the University of Bonn since 1958. At that time, this city was the provisional capital of the FRG as well as the seat of the West German parliament, government and ministries. Habs had a long record in politics related to medicine and academia. During National Socialism, he had been a member of the NSDAP, of the National Socialist Association for Physicians (NS-Ärztebund) and of the

\footnotetext{
${ }^{41}$ Peter Voswinckel, 'Paschen, Enrique Federico Mauricio', Neue Deutsche Biographie, 20 (Berlin: Duncker \& Humblot, 2001), 82; Wolfgang U. Eckart, 'Generalarzt Ernst Rodenwaldt', in Gerd R. Ueberschär (ed.), Hitlers militärische Elite: Von den Anfängen des Regimes bis Kriegsbeginn, Vol. 1 (Darmstadt: Primus, 1998), 210-22; Michael Kutzer, 'Rodenwaldt, Ernst Robert Karl', Neue Deutsche Biographie, 21 (Berlin: Duncker \& Humblot, 2003), 697-8.

42 The Abkommen über wirtschaftliche und technische Zusammenarbeit der Regierung der Bundesrepublik Deutschland und der Regierung der Republik Togo was signed on 20 July 1960; independence had been declared on 27 April 1960.

${ }^{43}$ Raphael Quarshie Avornyo, Deutschland und Togo (1847-1987) (Frankfurt am Main: Lang, 1989).

${ }^{44}$ Robert Cornevin, 'Olympio, Pedro (1898-1969)', Académie des sciences d'outre-mer: Hommes et destins (Paris: Académie des sciences d'outre-mer, 1975), 565.

45 Trutz von Trotha, Koloniale Herrschaft: Zur Soziologischen Theorie der Staatsentstehung am Beispiel des 'Schutzgebietes Togo' (Tübingen: Mohr Siebeck, 1994), 398-407.
} 
National Socialist Association for Lecturers (NS-Dozentenbund), and he had also been an officer in the SS. ${ }^{46} \mathrm{He}$ had taken part in a confidential meeting in 1943, which - among other topics - discussed inhumane experiments concerning sulfonamide and typhus on inmates of German concentration camps. After the war, he advised the new West German army (Bundeswehr) on ways to (re-)establish its medical service. ${ }^{47}$

In 1960, one of his deputies at Bonn University, Professor Dr med. Heinz Peter Rudolf Seeliger (1920-97), was commissioned with a consultancy on the health situation in Togo. This followed - strangely enough - an initiative by the West German Ministry of the Interior, where a 'health department' was in charge of all medical and health affairs before the creation of a ministry of health in $1961 .{ }^{48}$ Due to his previous work in the laboratory of the US forces in Heidelberg, Seeliger was far more internationally informed and minded than most of his German colleagues, although he had not worked outside the Western world at that point. ${ }^{49}$ Seeliger visited Togo for two months in 1961 and wrote a survey in close collaboration with international agencies such as the WHO. Formulated in both a German and French version, this then served as the basis for planning the agreed institute of hygiene. ${ }^{50}$ In a later publication on the trip, Seeliger described the Togolese expectations of Germany as 'an often touching affection towards the former protective power' in the hope of 'a decisive contribution to building the young state'. ${ }^{51}$ When the official additional bilateral agreement on the establishment of an institute of hygiene in Lomé was signed on 31 May 1965, construction of the institute building had already been underway for a year. Completed in 1967, it was designed and supervised by German architects and implemented by Togolese companies. The Republic of Togo provided the construction site, locally produced furniture, tax exemption for the import of necessary materials from abroad, transport and storage within the country, and various kinds of support for the accommodation of the German staff.

Upon completion of the building, Seeliger, then director of the Institute for Hygiene and Microbiology at Würzburg University since 1965 and thereafter consultant to the GAWI, referred once again to the colonial legacy:

on the whole, it should be noted that the building now makes an excellent impression. (. . ) Simple and functional and like a typical purpose-built structure, it fits beautifully into the government quarters of the capital of Lomé. (... ) Nevertheless, compared to the French institutes in Abidjan and Dakar, visited by the undersigned, the interior looks rather modest. However, it thereby achieves the required degree of frugality, while retaining a certain class. This state of affairs should be especially emphasised when informing the German public, as is desirable. ${ }^{52}$

Such remarks reveal a search for the right balance between self-confidence and modesty when approaching the new tasks, especially in comparison with well-established previous colonial nations.

\footnotetext{
${ }^{46}$ Ernst Klee, Das Personenlexikon zum Dritten Reich, 2nd edn (Frankfurt am Main: Fischer, 2007), 215.

${ }^{47}$ Ernst Klee, Auschwitz, die NS-Medizin und ihre Opfer (Frankfurt am Main: Fischer, 1997), 203: 311.

${ }^{48}$ Heinz P.R. Seeliger, '50 Jahre erlebte Mikrobiologie und Hygiene', Würzburger Medizinhistorische Mitteilungen, 9 (1991), 207-15: 211.

49 J. Müller, 'Heinz P.R. Seeliger zum 75. Geburtstag', mycoses, 39, suppl. 1 (1996), 9-10: 9.

${ }^{50}$ Heinz P.R. Seeliger, Expertise sur les possibilités de l'installation d'un institut d'hygiène au Togo faite comme résultat d'un voyage au Togo en août et septembre 1961 (n.p., n.d.); Heinz P.R. Seeliger, Gutachten über die Möglichkeiten eines Hygieneinstituts in Togo (n.p., 1961).

${ }^{51}$ Heinz P.R. Seeliger, 'Hygiene-Probleme in Togo', Archiv für Hygiene und Bakteriologie, 147 (1963), 307-48: 307.

52 Seeliger to Deutsche Förderungsgesellschaft für Entwicklungsländer, Würzburg 19.12.1967, 7, BArch B 213/21824. On Seeliger, see J. Müller, 'Nachruf Heinz P.R. Seeliger 1920-97', mycoses, 41, (1998), 13-14.
} 


\section{The German Contribution: Staff, Mentoring, Materials and Finances}

The operation of the institute was regulated in an additional agreement in 1967, granting German financial support for four years and German staff for three years. Running the institute was a joint German-Togolese enterprise and obviously functioned smoothly, apart from very rare German complaints such as in 1969: 'Despite all the goodwill, the Togolese have difficulties to provide their contributions.' 53 The first German team, all of whom had previous ties to the Institute of Hygiene at Bonn University, consisted of two doctors the project leader and head of the department of applied hygiene, and the head of the department of parasitology - as well as two medico-technical assistants, a mechanic and an electro-technician; a typist was later added.

Upon its opening in 1967, the institute was assigned several German academics who took on mentorships (Patenschaften). One of the mentors was Habs, another Seeliger. This kind of 'mentoring' by German university institutes or faculties of their counterparts in developing countries had already been recommended by a German expert meeting on 'experiences in establishing health care in developing countries' in 1962, where Seeliger had been one of the few university-affiliated participants. ${ }^{54}$ Habs also became involved in efforts to control disease in Togo by organising a polio immunisation programme, together with his wife, and - outside Africa - in efforts to eradicate malaria in Greece. ${ }^{55}$ Among the German mentors, Professor Dr med. Albert Herrlich (1902-70) was the figure with most experience outside Europe. He had been director of the Bavarian State Institute for Vaccination, including an Institute for Infectious and Tropical Medicine, since 1948, and had held the chair for comparative tropical medicine in the faculty of veterinary medicine at the University of Munich since 1964. ${ }^{56}$ Herrlich had spent most of his time from 1933 to 1939 in East Africa, Afghanistan and India, studying the genealogy of wheat in the Hindukush region in 1935 and visiting most countries of eastern and southern Africa between 1936 and $1937 .{ }^{57}$ After 1950, he devoted several trips to the study of acute problems of tropical medicine, eg. investigating a smallpox epidemic in India in $1958 .{ }^{58}$ Herrlich's participation in mentoring the Lomé institute is remarkable, since he had, in 1963, been an outspoken opponent of the establishment of permanent outposts of European institutes of tropical medicine in former colonial territories. He had considered these places as mainly suitable for training academic novices and not for long-term research. ${ }^{59}$ The high costs and the narrow focus on a single region instead of the broader information to

\footnotetext{
53 Aktennotiz über die derzeitige Situation des Institut National d'Hygiène, 22.8.1969, 2, BArch B 213/21824.

${ }^{54}$ Deutsche Stiftung für Entwicklungsländer (ed.), Erfahrungen beim Aufbau des Gesundheitswesens in Entwicklungsländern: Bericht über ein Expertengespräch in Berlin vom 16.-18. Oktober 1962 (Berlin: DSE, 1962), 56.

55 University Archive Bonn, MF 80-PA 112 Horst Habs, Letter Habs to university chancellor, Bonn 4 November 1976; 'Wichtige Forschung zu Salmonellen: Professor Horst Habs gestorben', General-Anzeiger Bonn (11 April 1987), 6 .

${ }^{56}$ Herrmann Knüttgen, 'Professor Dr Albert Herrlich †', Zeitschrift für Tropenmedizin und Parasitologie, 21 (1970), 116; Joachim Boessneck, 'Chronik der Tierärztlichen Fakultät', in Laetitia Böhm and Johannes Spörl (eds), Die Ludwig-Maximilians-Universität München in ihren Fakultäten (Berlin: Duncker \& Humblot, 1972), 281-346: 338.

57 Albert Herrlich, 'Auf der Suche nach dem Urweizen: Die Deutsche Hindukusch-Expedition 1935', Die Umschau, 40 (1936), 623-32; Albert Herrlich, Schwarze Reise: Vom Roten Meer nach Südafrika (Berlin: Oestergaard, 1937).

58 Albert Herrlich, 'Variola: Eindrücke von einer Epidemie in Bombay im Jahre 1958', Deutsche Medizinische Wochenschrift, 83, 34 (1958), 1426-8; Anonymous, 'Pocken: Jagd nach den Tätern', Der Spiegel (7 January 1959), 33-4.

${ }^{59}$ Hulverscheidt, op. cit. (note 29), 287.
} 
be gained by expeditions had been his main arguments against fixed research facilities; instead, he had proposed commissioning research to varying regions and for limited periods. After Herrlich's death in 1970, the parasitologist Professor Dr Gerhard Piekarski (1910-92) from Bonn University replaced him as mentor. ${ }^{60}$

In September 1969, the inter-ministerial committee of the West German government responsible for the project prolonged it for another two years and increased the expatriate staff. The hygienist, who was still also the project leader, and the parasitologist were supplemented by a bacteriologist while the number of medico-technical assistants was increased from two to four. A laboratory assistant for animals was also added. After these two years, the co-operation was formalised in an additional treaty of 15 September 1971.

As early as 1968 the West German Ministry of Economic Co-operation had praised the institute in almost lyrical terms:

The institute of hygiene as the centre of public hygiene excels by its enormous impact ['Ausstrahlungskraft']. It is one of the most important projects of German technical aid in Togo, which essentially functions in education and training beyond its diagnostic tasks. ${ }^{61}$

Its actual functioning in these different areas, however, needs to be looked at in more detail since the whole project was still far ahead of the general development of medical infrastructure in Togo. In his report of 1973, Dr med. Peter Scheiber, project leader since 1969 , criticised the fact that, at the time of the establishment of the institute, 'the place and the tasks for a central laboratory with the range of duties described were neither prepared nor even projected (...) in the public health system of Togo'. ${ }^{62}$ Only after 1970 did conditions regarding the supply of water and power, roads and 'self-confidence' improve. Nevertheless, in the report which they published in the journal of the German Medical Association, Scheiber and his predecessor Dr med. Georg Quincke, later a staff member of the WHO from 1969 onwards and finally its director of the Division of Food and Nutrition, described the start as being marked by a rapid increase in the number of samples and smooth collaboration with national authorities and international agencies such as the WHO. ${ }^{63}$ The same was said about the immunisations organised by the institute between 1967 and 1969. According to Habs, the provision of such vaccines and the less frequently needed anti-sera made 'the pioneering function of an institute for the future organization of the health system' especially visible. ${ }^{64}$ The national institute seems to have worked well from the very beginning as a laboratory, vaccination service and advisory body. With regard to the long-term perspective, however, the Togolese counterparts remained a major challenge.

\section{Opportunities for Togo: Capacity-Building, Training and Education}

Seen in the categories of German governmental budgets and public funds, the project remained one of 'technical aid' rather than 'German research abroad' or 'financial aid'. Its main aim was thus specific capacity-building rather than the production of

\footnotetext{
${ }^{60}$ Hans Martin Seitz and the editors, 'To Gerhard Piekarski on the occasion of his 75th birthday', Zeitschrift für Parasitenkunde, 71 (1985), 565-6; Heinz Mehlhorn and Hans Martin Seitz, 'In memoriam: Gerhard Piekarski, 5.10.1910-9.10.1992', Parasitology Research, 79 (1993), 91-2.

${ }^{61}$ BArch B 213/21824, Stellungnahme des BMZ vom 30.5.1968.

62 BArch B 213/21825, Schreiber, Peter: Darstellung der Situation des Instituts, Lomé 6.6.1973, 5.

${ }^{63}$ WHO, WHO Division of Food and Nutrition, WHO Press Release (27 May 1993) URL: http://www.unsyste m.org/scn/archives/scnnews09/ch7.htm.

64 BArch B 213/21825, Stellungnahme Habs zum Anschlussvertrag für das Projekt FE 923 - Hygiene Institut Lomé, Bonn 30.6.1973, 25.
} 
scientific knowledge or an increase in the financial resources available for health care and research. Co-operating German academics were well aware of this task: 'It cannot be overemphasised that there is long-term educational work ahead of us which concerns all kinds of staff at the institute. ${ }^{65}$

The initial Togolese staff consisted of an administrator, two medico-technical assistants 'trained in Germany, but still inexperienced', three workers for the garden, stables and cleaning, a driver, a servant for the scullery and a porter. ${ }^{66} \mathrm{~A}$ co-director and an administrator from Togo assisted the German academics in their organisational and bureaucratic tasks. Perhaps it was also this model of prolonged joint work that contributed to the prevention of struggles for power in the transition period. Such conflicts had occurred at the Pasteur Institute of Cameroon in the same year of 1967, where a parting French director and his colleagues blocked an African successor who was just returning from France. ${ }^{67}$

Concerning the main, capacity-building task, Seeliger had to disappoint expectations:

Employing Togolese counterparts (homologues) who can take over duties as collaborators of the heads of department cannot be expected in the near future, as only a few Togolese medical students have returned home after completing their education, and they were immediately charged with medical care. ${ }^{68}$

Between 1965 and 1970, university education for citizens of Togo was mainly provided at the Institut Supérieur du Benin. ${ }^{69}$ Again in 1969, a note in the German records referred to the 'seemingly hopeless counterpart situation' due to the medical students' lack of interest in these jobs. ${ }^{70}$ As late as 1972, the German project leaders still complained about the lack of Togolese academic staff, as there were hardly any 'candidates that were interested in questions of theoretical medicine' - although the number of Togolese doctors in the country had nearly doubled since the start of the project. ${ }^{71}$

An improvement could be hoped for from the most important Togolese development for the academic side of the project, ie. the foundation of a university at Lomé in 1970, which included a medical school. The academic staff of the institute provided practical instruction at the school in co-operation with the hospitals of ophthalmology and gynaecology/obstetrics and also offered scientific training for possible future researchers. As early as 1961, prior to the German-Togolese co-operation via the hygiene institute, German technical aid had supported the hospital in Tokoin, a suburb of Lomé. Five German doctors and two medico-technical assistants were employed there in 1971, when the hospital was becoming the clinical part of the new university's medical school. Further assistance through mentoring (Patenschaft) by German universities was explicitly requested from the Togolese side. ${ }^{72}$ Inter-university co-operation seemed to be regarded as a successful model for capacity building.

The 'capacity-building' activities of the institute also went beyond its own needs and medical academia. Besides training on the job for the Togolese academic staff of the institute and the contribution to medical education at the university, the institute organised

65 BArch B 213/21824, Schreiben Seeligers an die Deutsche Förderungsgesellschaft für Entwicklungsländer, Würzburg 19.12.1967, 27.

66 Ibid.

${ }^{67}$ Lachenal, op. cit. (note 30), 380-2.

68 Seeliger, op. cit. (note 65), 14.

${ }^{69}$ Avornyo, op. cit. (note 43), 211.

70 BArch B 213/21824, Aktennotiz über die derzeitige Situation des Institut National d'Hygiène, 22.8.1969, 2.

${ }^{71}$ Georg Quincke and Peter Scheiber, 'Das "Institut National d'Hygiene Ernst Rodenwaldt”: Bericht über den Beginn eines Projektes der deutschen Entwicklungshilfe', Deutsches Ärzteblatt, 69 (1972), 375-80: 444-6: 445.

72 BArch B 213/21824, Report of Dr Greiff on a journey to West Africa, 8 March 1971. 
special courses for laboratory assistants, hygiene assistants in the public health service and WHO fellows. ${ }^{73}$

\section{Academic Output: Scientific Research at the Institute}

The question as to whether and to what extent research was to be part of the institute's activities was far less clearly regulated than might be expected of plans involving German university professors. After all, they had been brought up in the Humboldtian tradition of a unity of teaching and research, complemented in the medical faculty by practical health care via clinical work and public health. In contrast to other institutes of medical schools or to medical institutes outside universities, institutes of hygiene had always been characterised by their combination of research and public health, ie. their dual function for science and for current medico-political or administrative purposes. In the nineteenth century, they had often been established as laboratories by local authorities and had only later been incorporated into universities, as occurred in Bonn about $1900 .^{74}$ Or they remained independent of a university despite their strong research activities, as in the case of Hamburg, which was for a time the largest institute of hygiene in Germany. Thus German academic hygienists were well acquainted with the hybrid position between laboratory research and routine work, between the production of new scientific knowledge and serving the country, eg. in vaccination and epidemiological surveillance. It remained unclear as to how far this double function was now also intended for the national institute in Lomé. The chances for the two fields were judged quite differently.

In his expert opinion on the institute of 1967, Seeliger stated bluntly: 'A research activity of its own cannot be considered, things given as they are', since for this activity there were other 'existing opportunities in Lomé'. ${ }^{75}$ Obviously, research was not even planned in the official description of the tasks of the institute, revealing a slight difference of views between the German development aid agencies and German academia. This tension becomes visible in publications too, sometimes even occurring within the same article, as in the above-mentioned 1972 journal of the German Medical Association. Here, diverging lists regarding the duties of the institute can be found in the information box on the one hand, which is obviously based on official sources, and in the report by the two German scientists on the other hand. The box only speaks of the institute's function 'as a reference laboratory for samples sent in, as a central "health office" of the republic and as a central institution for a system of outposts under construction, by which a network of the health system shall cover the whole country'. ${ }^{76}$ The authors, however, risked minor contradictions when they wrote that the institute 'took over the tasks of a laboratory for the public health service and, as such, shall perform examinations as well as research work in the field of public health [Volksgesundheit]'. Furthermore they stated that these tasks equalled those of 'a public health office [Medizinalbüro] for examination, responsible for the whole of Togo, which has an advisory function in the control of diseases and delivers the necessary documents for this purpose'. ${ }^{77}$ Solely a 'public health office' or also responsible for 'research work', what were the major tasks? The scientists explicitly emphasised research work as an equal task, whereas the institute's only official function

\footnotetext{
73 BArch B 213/21824, Jahresbericht 1968.

${ }^{74}$ Carl Schmiz, Die medizinische Fakultät der Universität Bonn 1818-1918: Ein Beitrag zur Geschichte der Medizin (Bonn: Marcus und Webers, 1920), 87.

75 BArch B 213/21824, Schreiben Seeligers an die Deutsche Förderungsgesellschaft für Entwicklungsländer, Würzburg 19.12.1967, 22.

${ }^{76}$ Quincke and Scheiber, op. cit. (note 71), 375.

77 Ibid.
} 
in the view of the German donor, ie. West German 'development aid' and the Republic of Togo was public health.

As far as can be surmised from the sources, this diversity of aims did not hinder the work of the institute, perhaps even resulting in the contrary. The backbone provided by the German contribution was the fact that staff stayed for at least a year, the minimum requirement suggested by Wilhelm Schulze, an army hygienist, bacteriologist and specialist for tropical medicine at the institute in 1969. Schulze also listed other necessary qualifications, including 'physical fitness', 'self-initiative' and independence in working and identifying problems, and 'the readiness to establish contacts' ${ }^{78}$ Mentor Habs appealed to the German public health service to supply experts of this kind by dispatching them to 'development aid' missions and reintegrating them afterwards, 'which would make a career in the public health service more attractive for some doctors' ${ }^{79}$ But the opportunity to do research also attracted promising junior scientists to the institute. Among these were the later directors of the hygiene institutes in Hamburg and Stuttgart, Jochen Bockemühl and Gerhard Schröter respectively, who probably would not have come as ordinary 'development aid workers'. Coming for research, they brought their scientific expertise to the institute with its increasingly Togolese academic staff. Short-term research stays by German junior researchers as 'project assistants' had already been provided for in Article 4 of the additional treaty of $1965 .{ }^{80}$ The mentoring senior scientists, all of them holders of university chairs or directors of institutes, were certainly more prepared to take on co-responsibility for the institute because it promised additional research opportunities. This was especially true of a parasitologist such as Piekarsky, who only had very minor public health tasks at home in Germany and was therefore much more of a pure academic than a practitioner of hygiene.

Nevertheless, the academic merits garnered by research remained almost completely on the German side, even when the scientific publications were in languages other than German, including French as the official language of Togo. ${ }^{81}$ To date, it has only been possible to identify three articles by the German researchers where a co-author has an obviously African surname. One of these two co-authors, A. Amédomé, was not even a staff member at the institute, but was instead in the Service des Contagieux, Centre Hospitalier Universitaire, Lomé (Togo), and had already published in France and Africa several times previously, once even on the issue of cholera under investigation in the article. ${ }^{82}$ The other author, K. N. Agbo, belonged to the academic staff of the national institute, as Medécin-chef of the Parasitology Section. ${ }^{83}$ The article in question was

\footnotetext{
78 Wilhelm Schulze, 'Als deutscher Arzt in Togo', Wehrmedizinische Monatsschrift, 15 (1970), $259-61$.

${ }^{79}$ Horst Habs, 'Zur Problematik der präventiven Medizin im Rahmen der Entwicklungshilfe', Das öffentliche Gesundheitswesen, 35 (1973), 566-71: 570.

${ }^{80}$ Quincke and Scheiber, op. cit. (note 71), 446.

${ }^{81}$ For example, Werner Beinhauer, 'Recherches sur la tuberculose bovine en afrique occidentale et centrale', Bulletin des epizooties en Afrique, 18 (1970), 329-32.

82 Jochen Bockemühl, A. Amédomé and A. Triemer, 'Gastro-enterites cholériformes dues à Vibrio parahaemolyticus sur la côte du Togo (Afrique occidentale)', Tropenmedizin und Parasitologie, 23 (1972), 308-15; Jochen Bockemühl, A. Amédomé, and A. Triemer, 'Vibrio parahaemolyticus Gastroenteritis during the El Tor Cholera Epidemic in Togo (West Africa)', American Journal of Tropical Medicine and Hygiene, 24 (1975), 101-104; A. Amédomé et al., 'A propos de 40 premiers cas de choleéra bactériologiquement confirmés traités au Centre national hospitalier de Lomé (Togo)', Bulletin de la Société médicale d'Afrique noire de langue française, 16, 2 (1971), 219-23.

83 Peter Scheiber, Reny A. Braun-Munzinger, Brian A. Southgate and K.N. Agbo, 'Epidemiological Studies on Onchocerciasis by Means of a New Field Technique', Bulletin of the World Health Organization, 53 (1976), 472-5.
} 
the first and only authorship for nearly a decade under the name of K. Agbo in an internationally listed medical journal. The next occurrence was in 1984, when a K. Agbo, technicien supérieur at the laboratory and parasitological services of the university hospital Lomé, started a long list of publications on parasitological issues with Francophone and Anglophone research partners. Perhaps K. N. Agbo's early co-authorship was also facilitated by his newly arrived European co-authors: the German Reny Anneliese BraunMunzinger (1948-90), who was accustomed to the co-operative practice of local coauthorship through her previous work with Indian researchers in India, and the British scientist Brian A. Southgate (1930-2011), who became well known for his support of nonEuropean researchers and who obviously saw this practice as an international standard. ${ }^{84}$ Yet on the whole, junior African researchers with an initial scientific training at the national institute could not further their potential academic careers by means of publications arising from the research activities of the German scientists. Most probably, the initiative, the design of the studies and the writing of the manuscripts are mirrored in this result: that almost exclusively Germans appear as authors. Even in the archival documents and apart from the occasional acknowledgement of 'technical assistance' in the publications, it usually remains unclear as to how far the Togolese counterparts were actually involved in, eg. the selection of areas and research subjects or the collection and examination of samples. There is just one very elaborate acknowledgment from 1976 and 1977 by Bockemühl in the context of his research on salmonella and shigella, conducted between 1971 and 1973:

The examinations reported in this paper have been performed under somewhat difficult field conditions and were only possible thanks to the sympathy and collaboration of the local authorities: the regional representatives of the government, health officers, nurses, sanitary inspectors, school teachers, and village headmen.

Special thanks are due to my team, who worked together for 16 months: Mr V. Kpelevi, Mr L. Lawson, Mr L. Pr. Agbodjan, Mr R. Apedoh, and Mr M. Sessou.

Serotyping of strains was performed at the Institute of Hygiene and Microbiology, University of Würzburg, by Mrs R. Miethke, Mrs D. Legat, Miss I. Voigt, and the National Reference Centre for Salmonella, Hamburg, by Priv.-Doz. [Senior lecturer] Dr R. Rohde. ${ }^{85}$

The three female German collaborators without a doctoral degree were probably medico-technical assistants and had been co-authors in two previous publications. ${ }^{86}$ The names of the African collaborators were not mentioned again in the second part of the publication and never recurred as authors of articles in international medical journals. ${ }^{87}$

\footnotetext{
${ }^{84}$ Hans-Jochen Diesfeld, Sukhendra Nath Dutta and Reny A. Braun-Munzinger, 'Immundiagnostische Untersuchungen bei Personen aus einem Wucheria bancrofti-Endemiegebiet', Zeitschrift für Tropenmedizin und Parasitologie, 24 (1973), 439-46; 'Reny Anneliese Braun-Munzinger, b. 24 March 1948, d. 16 January 1990', http://www.landofthebuckeye.net/p329.htm (4 June 2014); Roger Webber, Peter Smith, Paul Fine, and David Bradley, 'Obituary: Brian Southgate', June 2010, http://www.lshtm.ac.uk/alumni/news/brian_southgate.html (4 June 2014).

85 Jochen Bockemühl, 'Salmonellosis and Shigellosis in Togo (West Africa), 1971-3, I: Carrier Rates in the Rural Population', Tropenmedizin und Parasitologie, 27 (1976), 112-20: 119-20.

86 Jochen Bockemühl, Rolf Rohde, R. Miethke, D. Legat and I. Voigt, 'Zehn neue Serotypen des SalmonellaSubgenus I, isoliert von gesunden Ausscheidern in Togo (Westafrika)', Zentralblatt für Bakteriologie, Parasitenkunde, Infektionskrankheiten und Hygiene, 233 (1975), 43-9; Jochen Bockemühl, Rolf Rohde, D. Legat, R. Miethke, I. Voigt, 'Zehn neue monophasische Serotypen des Salmonella-Subgenus I und zwei serologische Varianten monophasischer Stämme', Zentralblatt für Bakteriologie, Parasitenkunde, Infektionskrankheiten und Hygiene, 233 (1975), 565-71.

87 Jochen Bockemühl, 'Salmonellosis and Shigellosis in Togo (West Africa),1971-3, II: Infections in the Urban Population of Lome',Tropenmedizin und Parasitologie, 28 (1977), 377-83: 383; search for author's name in PubMed, 8 May 2014.
} 
Thus, even when a German scientist clearly wanted to acknowledge the essential work of African staff members, German academic conventions seemed to exclude their function as co-authors. This story of academic publishing serves as a further telling example of how 'medico-scientific practices may crystallise post-colonial obscenity, by defining, incorporating, and exploiting socio-racial inequities, ${ }^{88}$ as formulated concisely by the French historian Guillaume Lachenal.

\section{The Impact of the Project}

The final plan had been that the institute could be handed over to the authorities of Togo in early 1976 after a year under the responsibility of a Togolese director advised by his German predecessor. ${ }^{89}$ Thus the whole project, from the start to the transition, was intended to last less than ten years, a goal which was, in fact, ultimately achieved. When the institute was handed over to the Togolese ministry of health and social services on 9 January 1976, the high esteem for the institute from both sides was indicated by the presence of several Togolese ministers and several German representatives, including the two mentors Seeliger and Piekarski. ${ }^{90}$ There was no evidence of conflicts during the transition of power such as those which again paralysed the previously mentioned Institut Pasteur in Cameroon between 1974 and $1980 .^{91}$

Considering contemporary German journalism's widespread criticism of German development aid or emergency aid in other places and its particular, politically motivated attention to German relations with the dictatorial ruler Eyadéma (president, 1967-2005), it should be mentioned that the hygiene institute in Lomé remained without unfavourable media coverage in Germany. The institute had been requested by a still legitimate government and was clearly in the interests of the whole country; it was in line with the German shift towards preventative medicine and academic research in development cooperation; its construction was not delayed in any notable way; collaboration occurred without major conflicts; and the aim of 'capacity-building' by training counterparts was achieved in so far as Togolese heads of departments were able to take over the responsibilities in routine work at the end of the project. The institute was not a foreign body, but formed part of the national health system. As an investment in public health, it could be regarded as a success. In fact, the institutes in Lomé and Bangkok were the only two positive exceptions explicitly mentioned in an otherwise devastating evaluation of health projects by a senior official in the German Ministry of Economic Co-operation in 1968 , their success being particularly attributed to continuous mentorship leading to new forms of partnership..$^{92}$

Beyond the routine work of the institute, Togo profited from at least some of the data gathered by German scientists during research. The studies - mostly supported by the DFG - were largely epidemiological, primarily giving information on the health situation in the country concerning the frequency of certain germs and, to a lesser degree, contributing to universal medical knowledge such as bacteriological taxonomy. Research especially

\footnotetext{
${ }^{88}$ Lachenal, op. cit. (note 4), 443.

${ }^{89}$ BARch B 213/21825, Peter Scheiber, Darstellung der Situation des Instituts, Lomé 6.6.1973, here 12.

${ }^{90}$ BArch B 213/21825, Ambassador Heider to Foreign Office, 15.1.1976.

91 Lachenal, op. cit. (note 30), 382-4; Lachenal, op. cit. (note 4), 432-7.

92 Ministerialrat Dr Martin Greiff, BMZ, to Ministerialdirigent I B, BMZ, Bonn 7.11.1968, Ad-hoc Kommission Gesundheitshilfe im Jahr 1969, BArch B213/5459 (314/T4012) 1964-72.
} 
concerned common bacterial diseases such as cholera ${ }^{93}$ and salmonellosis, ${ }^{94}$ as well as shigellosis ${ }^{95}$ and gonorrhoea. ${ }^{96}$ The academic publications were often a side-effect of routine activities at the national institute such as health examinations of 'prostitutes' and hygiene checks of schools, wells and food. Emphasis was placed on the 'importance of unbiased, critical parasitological examinations', as opposed to simple routine diagnostics for expected findings. Only in this way was it possible to establish the presence of certain worm eggs which had not previously been described for West Africa or to identify a cholera-like epidemic due to Vibrio parahaemolyticus. ${ }^{97}$

The parasitologist Piekarski did not publish any research work himself on the health situation in Togo. But the institute's research interest was extended from bacteriology to parasitological diseases, such as Bancroftian filariasis, ${ }^{98}$ onchocercosis, ${ }^{99}$ malaria, bilharzia and sleeping sickness, ${ }^{100}$ during the his post-1970 mentoring period and even for many years after the completion of the development project in 1976. Reny BraunMunzinger's joining of the national institute gave it an expatriate medico-technical assistant who had previously worked at the University of Heidelberg and would do so again after her time in Togo. She thus broadened the institute's scientific connections beyond the initial mentoring universities of Bonn, Würzburg and Munich. In these studies towards the end of the project, acknowledgement is made of financial support other than that provided by the DFG with its exclusive responsibility for research, eg. 'by the Ministry of Public Health and Social Affairs, Togo and by the Agency for Technical Co-operation (GTZ), Eschborn, Federal Republic of Germany'. ${ }^{101}$ This indicates a full integration of scientific research into the development project and the national health system.

Meanwhile, however, ideas on scientific relations were changing in Germany. In 1971, the professor of economics Peter Meyer-Dohm (*1930), who was later head of Bochum University (1975-9), demanded that the common 'transfer of knowledge' must

\footnotetext{
93 Jochen Bockemühl and A. Triemer, 'Reappraisal of Venkatraman-Ramakrishnan Sea-Salt Fluid as Transport Medium for Pathogenic Vibrios (El Tor vibrios, Vibrio parahaemoylticus) in Togo (West Africa)', Tropenmedizin und Parasitologie, 25 (1974), 236-42 [with the affiliation of the National Institute in Lomé, but the corresponding address in Würzburg, and acknowledging the 'technical assistance of Mr V. Kpelevi']; Jochen Bockemühl and A. Triemer, 'Ecology and Epidemiology of Vibrio parahaemolyticus on the Coast of Togo', Bulletin of the World Health Organization, 51 (1974), 353-60; Jochen Bockemühl and Gerhard Schröter, 'The El Tor Cholera Epidemic in Togo (West Africa) 1970-2', Tropenmedizin und Parasitologie, 26 (1975), 312-22; Jochen Bockemühl and D. Meinicke, 'Value of Phage Typing of Vibrio cholerae biotype eltor in West Africa', Bulletin of the World Health Organization, 54 (1976), 187-92.

94 Jochen Bockemühl, Georg Quincke and Rolf Rohde, 'Über neue Salmonella-Stämme aus Togo', Zentralblatt für Bakteriologie, Parasitenkunde, Infektionskrankheiten und Hygiene, 210 (1969), 560-6; Jochen Bockemühl et al., 'Dreizehn neue Salmonella-Typen des Subgenus I und drei serologische Varianten', Zentralblatt für Bakteriologie, Parasitenkunde, Infektionskrankheiten und Hygiene, 216 (1971), 323-32.

95 Bockemühl, op. cit. (note 85 and 87).

96 Georg Quincke, 'Über die Penicillinempfindlichkeit von in Lomé, Togo, isolierten Gonokokken', Zeitschrift für Tropenmedizin und Parasitology, 21 (1970), 433-7.

${ }^{97}$ Quincke and Scheiber, op. cit. (note 71), 380; Gerhard Schröter and Heinz P.R. Seeliger, 'Zielsetzung und Problematik bakteriologisch-serologischer Untersuchungsprogramme an einem Hygiene-Institut in Westafrika', Das öffentliche Gesundheitswesen, 34 (1972), 451-9: 458.

98 Peter Scheiber and Reny A. Braun-Munzinger, 'Bancroftian Filariasis in Togo, 1: A Comparative Field Study of the Membrane Filtration Concentration Technique and Conventional Blood Films', Tropenmedizin und Parasitologie, 27 (1976), 224-8.

${ }^{99}$ Reny A. Braun-Munzinger, Peter Scheiber and B.A. Southgate, 'Simplifying Modifications to the Microtitration Plate Technique for Onchocerciasis Surveys', Transactions of the Royal Society of Tropical Medicine and Hygiene, 71 (1977), 548-9.

100 BArch B 213/21824, Beinhauer: Tätigkeitsbericht No 1/1971.

101 Scheiber, Braun-Munzinger, Southgate, and Agbo, op. cit. (note 83).
} 
be supplemented or even replaced by independent 'production of knowledge' by and in 'developing countries' - anything else would by 'academic colonialism'. ${ }^{102}$ Scientists of the 'developing country' should have their share in the research work and its results. ${ }^{103}$ As noted above, the project did not contribute much in this regard. Several factors stood in the way of achieving more than training for the routine tasks of a central national laboratory: less than a decade was probably far too short; the mentor Herrlich had doubted the chances of fruitful research work in a permanent place in the tropics anyway; the project leaders hinted at the difficulties of keeping up the standards to which they were accustomed at home under these conditions; ${ }^{104}$ researchers preferred serological testing at home in Germany to the difficulties and expenses involved in establishing further bacteriological methods in Togo; ${ }^{105}$ and - probably most important - Togolese staff with academic qualifications were scarce and were already overburdened with routine tasks. Obviously, the project was ill-suited for capacity-building in scientific research. This would have demanded far more commitment from all sides and perhaps also conditions within the country that would not be achieved for quite some time.

A further task and development project which was started two years after the completion of the original development project brought increased importance to research at the institute. In 1978, the GTZ ${ }^{106}$ supported the establishment of an onchocerciasis reference laboratory to be directed by the parasitologist Hartwig Schulz-Key from the Hamburg Institute for Naval and Tropical Diseases. Schulz-Key retained this responsibility even after moving from Hamburg to the University of Tuebingen. However, the site for future research was moved from the capital to the regional hospital of Sokodé, the centre of onchocerciasis control. The institute's research centre flourished within this large project, which had already been started by the WHO in 1974 and received support from the World Bank and the European Economic Community (later European Union), among others, offering research opportunities in a tropical place over the years to more than a hundred, mostly German, junior scientists in the fields of medicine and biology ${ }^{107}$ until the present day.

Following the loss of these research opportunities to the regional hospital of Sokode, the institute in Lomé also had to give up the name it had adopted in 1967 to honour its German donor and early German work in Togo. When the West German Army decided to remove the name of Ernst Rodenwaldt, incidentally one of Piekarski's early mentors in the late 1930s, ${ }^{108}$ from the name of an institute in Koblenz in Germany in March 1998, after his connivance with inhumane human experimentation during National Socialism had become widely known, the Togolese authorities followed suit in October of the same year. The close relations between Germany and Togo thus even influenced issues not related to the African continent and development co-operation.

\footnotetext{
102 Peter Meyer-Dohm, 'Wissenschaftliche Beziehungen als Entwicklungsfaktoren', in Horst Sander and Dietrich Stein, Beziehungen deutscher wissenschaftlicher Institutionen zu Partnern in Entwicklungsländern: Universitäten, wissenschaftliche Hochschulen, Max-Planck-Institute, Bundesforschungsanstalten (Stuttgart: 1971), 11-37: 14.

103 Ibid., 29-30.

104 Quincke and Scheiber, op. cit. (note 71).

105 Bockemühl, op. cit. (note 85), 119.

106 See note 28 .

107 Andreas Sentker, 'Die Blinden vom Fluß', Zeit, 1 March 1996.

108 H.E. Krampitz, 'Gerhard Piekarski: 75 Jahre', Infection, 13, 5 (1985), 246.
} 


\section{Conclusions and Outlook}

The two major research questions - the relationship between West Germany and Togo and between medical academia and 'development aid' - have been answered to quite different extents due to the respective content of the German sources. The Eurocentric reports and correspondence reveal more about the interaction between development politics and biomedical science than that between the Germans and Togolese.

Involving West German universities in 'development aid' projects for health was common from the beginning. The political administration invited academia to play a role in what were both old and new fields. There appeared to be a necessary connection between the 'progress' and 'modernity' that 'development aid' claimed to bring and the promises of science - despite the obvious fact that the first was directed towards what were regarded as the most backward regions and the latter strived to be at the most advanced edge of human progress. Unequal partners had to negotiate their terms and seem to have done so to a certain degree of satisfaction on both sides.

However, the area of expertise for which university members were sought remained limited in the West German scenario during the first two decades of development cooperation. While non-medical academic experts in Britain such as health economists Richard Titmuss and Brian Abel-Smith were also commissioned with recommendations on comprehensive health care services in countries of the global south, West German professors were asked only for infectious disease control and clinical work. This mirrors two characteristics of Germany: its previous pivotal role in hygiene and bacteriology (which, of course, equally holds for British and French institutions on tropical health) and its lack of a continuous and recent colonial experience in medical administration. In view of the interwar German approach of social hygiene, a move towards social medicine as known from late British colonial policy could also have been expected from a continuing German colonial medical administration. The case studied here is thus typical of West Germany of the period, since academic expertise was not expected for health care in general. Medical academics were expected to contribute only to medical education and to establishing institutes on viral, bacterial and parasitological diseases or general hygiene, including toxicology, while returning German doctors were invited to contribute their expertise on the practical level of health care only. ${ }^{109}$

The first task of academics was consultancy to the West German government, since the government agencies for 'technical aid' did not yet have relevant experts of their own in these early years and benefited from temporarily hiring academics from university institutes without having to offer permanent jobs in Germany. Thus these experts travelled to the tropics in order to identify health problems that would need special academic expertise in the relevant country. A decade later, by 1973, the West German press maintained that the 'method practised by the Ministry of Economic Co-operation in sending ad hoc consultants, usually travel-happy university professors, on exploratory trips for a week has proved to be a failure' since 'permanent qualified observation and administrative support on the spot was lacking'. ${ }^{110}$ However, this accusation - typical of the increasingly sceptical attitude of the early 1970s towards development aid - hardly matches the project discussed here. Even before the professors visited the country, the host

\footnotetext{
109 Deutsche Stiftung für Entwicklungsländer, ed, Erfahrungen beim Aufbau des Gesundheitswesens in Entwicklungsländern: Bericht über ein Expertengespräch in Berlin vom 16. - 18. Oktober 1962 (Berlin: Deutsche Stiftung für Entwicklungsländer, 1962).

${ }^{110}$ Werner Dolph, 'Die ungeliebten Experten', Die Zeit (15 June 1973), 54.
} 
country had expressed the desire for the institute, and its establishment was principally agreed between the governments. The academic experts were influential in determining the areas of work, ie. the diseases to be addressed, the methods required, and the staff and equipment needed. As Togo did not have any specialists in these fields, the project itself was mainly based in this case on the plan drawn up by the German academic who first visited the country.

After the planning and construction of the institute, the next task for the universities was the provision of both technical and academic German staff. This was a further advantage for the federal ministries, which thereby gained privileged access to suitable staff. But the German institutes also profited from being able to offer what were often well-paid and attractive jobs as well as research opportunities to their post-doctoral members. Here, two different groups of biomedical experts emerged, reflecting the continuing tension between science and the health services, or academia and development co-operation: the doctors who held jobs at the institutes in Africa for a year or more did not usually pursue academic careers later, but rather stayed in international or development organisations, whereas those who stayed in Africa for research projects only became professors or directors afterwards for the most part. Thus the increasing West German split between academic experts on communicable diseases at universities and other research institutes on the one hand and public health officers in the civil service on the other was also made manifest in international co-operation.

In Togo, both areas differed considerably in terms of success. The main task, so-called 'capacity-building', was fulfilled for routine activities through collaboration between the German and Togolese counterparts. Building up local research capacities, on the other hand, remained difficult. Periods spent in Europe by Togolese students, mainly as part of their doctoral studies, seem to have been a precondition for acquiring the skills necessary to carry out research independently. Long-standing co-operation which continued after the end of the development project was the decisive condition for building up research capacities. Professor Fühner, head of the similar project in Kabul mentioned above, had demanded three phases, each of about three years: (1) establishing routine work, (2) sending the counterparts to Germany for further training, and (3) transferring responsibility for research to them by reducing German staff. ${ }^{111}$ This time frame of roughly a decade was quite a challenge for common 'development aid'. Before the proclaimed shift to 'sustainability' in the fourth UN 'development decade', beginning in 1990, development projects usually envisaged a short timeline that was not suitable for developing research capacities. The often criticised 'hyperoptimism' of development workers regarding the feasibility of transferring the knowledge, skills and necessary approaches within, eg. a twoyear stay, seemed to be especially ill suited to the long formation period of researchers. ${ }^{112}$ Academic co-operation offered better opportunities from the early 1970s. Its common timescale of decades instead of years, its post-graduate training or research in German institutions and its mutual visits financed by funding agencies for research and higher learning enabled it to follow and complement the initial 'development project'.

While the story documented in this paper ends in that decade, academic relations between (West) Germany and 'developing countries', especially in Africa, continued. They will therefore be the subject of the following short overview, which introduces

${ }^{111}$ Fühner, op. cit. (note 31).

112 Philipp H. Lepenies, 'Lernen vom Besserwisser: Wissenstransfer in der "Entwicklungshilfe" aus historischer Perspektive', in Hubertus Büschel and Daniel Speich (eds), Entwicklungswelten: Globalgeschichte der Entwicklungszusammenarbeit (Frankfurt am Main: campus, 2009), 33-59. 
further comparisons and aspects. Since the 1970s, these relations received regular attention and financial support in both the academic and development sectors. ${ }^{113}$ The Institute for Tropical Hygiene and Public Health at Heidelberg University became a centre for north-south co-operation for more than just infectious diseases, as its major topics included midwifery and nutrition, the latter also being found at the University of Giessen. Research on tropical medicine in tropical countries gained new momentum even beyond governmental interests. In 1981, the Hamburg Institute of Naval and Tropical Diseases opened a research laboratory in Lambarene, Gabon, the former place of work of the famous doctor Albert Schweitzer. This was done without German public funding and was entirely based on private donations. ${ }^{114}$ On the whole, links between development co-operation and academia decreased despite, or perhaps because of, special funding that the DFG and the DAAD started by programmes for academic co-operation with 'developing countries'. Meanwhile the German agencies for technical and financial co-operation (the GTZ and the West German development bank) had their own health experts and professional external consultants, so that they no longer always needed professors and lecturers for expertise in this area. At the same time, the German universities could rely on previously established institutions for research and higher education in their partner countries. Such institutions no longer had to be built from scratch as part of development projects - and probably would no longer have been built anyway within the new international health policies of the late 1970s directed towards Primary Health Care.

This tacit institutional separation of medical academia and 'development co-operation' was partly stopped with a series of new initiatives after 2000, when increased funding for global health emerged. Funds from implementing the Millennium Development Goals (MDGs), the Global Fund to Fight AIDS, Tuberculosis and Malaria (GFATM) and the Global Alliance for Vaccines and Immunisation (GAVI) boosted research on neglected health issues and operational research in particular in the countries concerned - alongside these initiatives' dominant activities with more immediate effects. At the 31 st G8 summit in Gleneagles in 2005, co-operation with Africa was declared a task for all ministries of the participating countries, including those with responsibility for education and research and for health. It was thus taken beyond the narrower focus of development co-operation. ${ }^{15}$

The (re-)united Germany reacted to these tasks by also providing additional funding and new medical research programmes. Thus, the challenges of the 1960s in integrating public health and academic research on communicable diseases within the framework of international co-operation returned under the new conditions of twenty-first century globalisation. It will be interesting to see to what extent history repeats itself or whether fundamental changes in national policies, scientific attitudes and international co-operation since the 1960s lead to different results in the future.

\footnotetext{
113 For example, Peter Meyer-Dohm (ed.), Bildungsökonomische Probleme der Entwicklungsländer (Tübingen: Erdmann, 1978); Deutscher Akademischer Austauschdienst in Zusammenarbeit mit Deutsche Gesellschaft für Technische Zusammenarbeit und Deutsche Stiftung für Internationale Entwicklung (ed.), Hochschule, Wissenschaft und Entwicklung in Afrika (Bonn: DAAD, 1980).

114 'Nur Almosen: In Lambarene, wo Albert Schweitzer wirkte, eröffnete das Hamburger Tropeninstitut ein Forschungslabor', Der Spiegel (11 May 1981), 213-20.

115 Inga Müller, 'Perspektiven für die wissenschaftlich-technologische Zusammenarbeit Deutschlands mit Subsahara-Afrika: Potentialanalyse', Deutsches Institut für Entwicklungspolitik, Discussion Paper 17/2006 (Bonn: DIE, 2006).
} 